\title{
Can Regional Free-Trade Bring Positive Impact on Local Farmers? \\ (A Study on the Ornamental Fish Farmers in Depok City, West Java, Indonesia)
}

\author{
Fentiny Nugroho ${ }^{1}$, Marsudi ${ }^{2}$ \\ \{fentiny2015@gmail.com ${ }^{1}$,dhyydi@yahoo.com² \} \\ ${ }^{1,2}$ Department of Social Welfare, Faculty of Social and Political Sciences, Universitas Indonesia
}

\begin{abstract}
There are arguments about free-trade, including the regional one. Many people support it, stating this can bring wealth. While others are against it, and view that causes negative impact. This qualitative study with descriptive type uses purposive informant determination techniques. Data collection is in the form of literature and document studies, in-depth interviews and observations of several categories of informants: ornamental fish farmers, formal and informal leaders, and related institutions at the local government of Depok. This study found that ornamental fish farmers in Depok, Indonesia have succeeded in exploiting and benefiting from regional free trade, mainly because the products they sell are not owned by other countries and there are marketing channels to the export market. But there are also obstacles that need to be corrected and because of their structural nature, government support is needed.
\end{abstract}

Keywords: Free-trade, positive impact, regional, ornamental fish farmer.

\section{Introduction}

Free-trade is taking place in many countries. There are fierce arguments about regonal and international free-trade. Many people support it, stating this can bring the people's wealth. While many are against it, and regard that it will bring negative impact to the countries, like Indonesia. This view is supported by empirical data showing the negative impact of free-trade [1]. Maurizio Busso [2] reveals that the liberalization of farming and food can increase extreme global poverty to be 0,2 persen, as a result of global inequality. The other research conducted by Gloria Soto [3], claims that the implementation of free-trade agreement in North America has had significant impact on environment degradation, especially deforestation in Mexico. In Indonesia, mass media cover some issues related to the free-trade, like the bankcrupcy of businesses in the country, because they are incapable of competing with the businessman from other countries. Many protests of sugar cane farmers, fishermen, labours, etc are also in coverage of mass media.

However, this study raises the topic of the positive implications of free-trade in Indonesia, especially among the ornamental fish farmers. It is interesting that they seem to be successful in maximizing international free-trade. The research question is: How is the impact of regional free-trade on the Ornamental Fish Farmers in Depok City, West-Java, Indonesia? This study gives a contribution to the welfare endeavour: what lessons learned can be taken in order to bring positive impact of free-trade and make it beneficial to our local farmers

This study uses a qualitative approach. According to Rubbin and Babbie. qualitative research is a research method that emphasizes deep understanding that seeks to gain deeper 
meaning from human experience, develops existing theories, and observes or observations that are not displayed in the form of numbers [4]. This research was conducted in Depok, West Java Province, Indonesia. Data collection techniques include Literature and Document Studies, In-depth Interviews and Observations. The research informants consist of: ornamental fish farmers, formal and informal leaders, and related institutions at the local government of Depok.

\section{Research Result and Discussion}

The research finds that the ornamental fish farmer in Depok are anomaly and against the common assumption that free-trade brings negative impact on local farmers. They show optimism in addressing the implementation of the free market. The sense of optimism of the ornamental fish farmers of Depok is not without reason; when the free trade has not been fully implemented, they had succeeded in expanding their production market to the countries that become trading partners of Indonesia.

Based on the results of the study, the type of ornamental fish "Tetra" is a superior commodity of farmers / cultivators of ornamental fish in Depok. There are several factors that underlie so that this species becomes a superior commodity of farmers, in addition to the appearance of attractive fish and much in demand by the market, the most distinctive is the type of Tetra ornamental fish which can only be cultivated in Curug and several other villages in Bojongsari District, Depok, while in the Amazon (America) itself, the place of origin of this type of ornamental fish "Tetra" was not successfully cultivated; the existence of these ornamental fish can only be in the wild (Amazone river). An informant, Tohir said "this type of Tetra Ornamental Fish has only been successfully cultivated in Curug and its surroundings. This is due to the condition of temperature and $\mathrm{pH}$ of water (5-6) in Curug and its surroundings which strongly supports the 'Tetra' type ornamental fish cultivation". Related to productivity, according to Agus (local government), groups of ornamental fish cultivators in Depok continue to increase their productivity from year to year, especially when the farmers have penetrated regional markets. In fact, because of high demand, especially for neon fish, farmers often run out of stock. The high demand is due to the quality of Ornamental Fish, having strong quality and competitiveness. Their production in recent years has increased, in addition to the increasing market demand, the increase in production is carried out as part of farmers' strategy to survive in the increasingly fierce era of competition, so although the price has not increased significantly, but quantity which is multiplied or increased to get better income.

According to an informant (Tohir), the exporters of Ornamental Fish will contact ornamental fish suppliers to convey the needs of the types and quantities of ornamental fish needed to be exported to the international market. The suppliers went to groups of ornamental fish farmers in Depok to collect the types of ornamental fish needed by exporters.. Furthermore, the collector sells it to exporters who are currently the only one in Depok as Ornamental Fish exporter. Furthermore, according to him, it is not just quantity, but the quality of ornamental fish produced by Depok farmers is considered the best in the world by Singapore importers. One of the main exports of farmers is Neon Tetra ornamental fish. This fish has a quality that is capable of defeating products from other countries abroad. According to Prasetio, Indonesian ornamental fish exports, according to international trade records, UN Comtrade is in the third position of world ornamental fish exporters, under Spain and Japan or above the Czech Republic and Malaysia. Currently the ornamental fish they produce have been marketed to some regional countries, for example Singapore, Qatar, and several countries 
in Europe, even to Africa. It appears that ornamental fish farmers in Depok were overwhelmed to respond to the current market demand, mainly demand from the international market through exporters, especially for the superior commodity of farmers, namely "Tetra" ornamental fish. According to an informant, Saidi, this case of foreign market has helped to improve the socio-economic life of the people in Curug and Bojongsari in general. At present, the efforts of farmers have absorbed labor in the Curug environment, contributed and participated in social activities, and contributed to the development of Depok City in general. Their contribution to regional development not only helps infrastructure development, like needs of road repairs, but also various other people's needs, for example in terms of economic empowerment; they also increase people's purchasing power and eliminate unemployment and poverty.

The production costs should still be minimized. The inefficient production process carried out by ornamental fish farmers is also confirmed by an informant (Mamud). The production costs continue to be significantly increased, while the price of ornamental fish tends to be static from year to year, even declining in price. Furthermore, according to him, the main problem now is that the type of "Artemia" cannot be produced domestically or imported, while for certain periods in the cycle of ornamental fish cultivation it must use the type of feed "Artemia". At present, what the farmers can do is holding the product marketed if the price of fish in the market is too low, if the price has returned to be normal, the fish will be marketed again. According to Tohir, in addition to the cost of the above fees, other costs incurred by farmers are interest costs on loans, both loans from banking institutions and nonbanking institutions. According to him, most farmers or cultivators of ornamental fish in Curug-Depok do not have their own capital, still expect capital assistance from the government or loans from banking institutions. Farmers tend to use non-banking institutions that allow getting loans faster with conditions that are not too complicated, eventhouh with a fairly high interest.

\subsection{Discussion}

Increasing demand for Depok ornamental farmers, then responded by farmers by increasing their capital capacity as a systematic effort to increase productivity and answer market demand. This means that what Goldin and Reinert (2007) stated that when free trade is implemented it will have a positive on expanding market access, increasing demand, and increasing productivity in the era of free trade. However, the farmers' production process tends to be inefficient because there are still some production costs that can be minimized [5].

Many things underlie the ability of Depok ornamental fish products to penetrate international markets. Some of these things include:

a. The quality and types of ornamental fish produced by ornamental fish farmers in Depok

City have specifications and uniqueness that are not owned by other ornamental fish

farmers outside of Depok or in other countries.

b. The support of the central government and regional governments through the implementation of good and appropriate cultivation training, as well as assistance with cultivation equipment and venture capital assistance for the farmers.

Some points stated above indirectly confirm some of the supporting variables of competitiveness put forward by Fane [6] and Porter [7] through the concept of diamond analysis, among others, the factors of strategy and structure that greatly contribute to the creation of competitiveness of business actors, including farmers in this research study.

Porter [7] in his generic strategy explains that there are three strategies used by business actors in winning competition in increasingly competitive markets, namely: cost strategies, 
differentiation strategies, and focused strategies. In this study, it can be seen that the strategy pursued or used by ornamental fish farmers in Depok is a differentiation strategy, namely creating a product or service that has distinctiveness, uniqueness or difference with other similar products that is not owned by ornamental fish produced by other ornamental fish farmers in other regions and other countries. In addition, another strategy undertaken by farmers is the selling price strategy, where a significant increase in selling prices is greatly avoided by farmers or ornamental fish farmers in Curug-Depok, what farmers do is increase productivity to get increased income.

Furthermore, the government through its programs and policies is another important variable in creating competitiveness of businesses or small farmers in the era of open competition [8]. This study indicates that the support provided by the central and regional governments, both through training, production equipment assistance, and capital assistance, significantly contributed to the birth of ornamental fish farmers in Depok which have high competitiveness capacity. However, as indicated by Nugroho and Kusumastuti [1], some structural factors can also affect the farmers performance, such as, credit access to bank and increasing prices of production materials. This needs Government support so that the productivity of ornamental fish farmers continues to increase so that they can continue to increase exports and improve their welfare.

\section{References}

[1] F. Nugroho and R. Kusumastuti, "Improving the Quality of Local Apples as Specialty Crops to Build Competitive Advantage in Free-Trade," Int. J. Appl. Bus. Econ. Res., vol. 15, no. 24, pp. 595-604, 2017.

[2] M. Busso, R. De Hovos, and D. Medvedev, "Free Trade in Agriculture and Global Poverty," World Econ., vol. 34, no. 12, pp. 2019-2043, 2011.

[3] Gloria, "Trade Liberalisation and Poverty Reduction In Vietnam," J. Polit. Policy, vol. 40, no. 3, pp. 471-491, 2012.

[4] W. L. Neumann, Social Research Method: Qualitative and Quantitative Approach. Fifth Edition. Boston: Allyn and Bacon, 2003.

[5] I. Goldin and K. Reinert, Globalization for Development: Trade, Finance, AID, Migration, and policy; Revised Edition. A Copublication Of The World Bank and Palgrave Macmillan, 2007.

[6] G. Fane, "Trade Liberalization, Economic Reform and Poverty Reduction in Lao PDR," Asia Pacific Econ., vol. 11, no. 2, pp. 213-226, 2007.

[7] M. E. Porter, The Competitive Advantage of Nations. New York: The Free PressSoto, 1990.

[8] Marsudi, Perdagangan Bebas dan Implikasinya bagi Kemiskinan Petani Lokal di Indonesia; Studi pada Petani Padi di Desa Pasir Telaga Karawang. Jakarta: FISIP UI, 2016. 